\title{
Selenomethionine increases proliferation and reduces apoptosis in bovine mammary epithelial cells under oxidative stress
}

\author{
S. G. Miranda, ${ }^{\dagger} \dagger$ N. G. Purdie, $\dagger$ V. R. Osborne, $†$ B. L. Coomber, $\neq$ and J. P. Cant $\dagger^{1}$ \\ *Department of Animal Science, University of Zulia, Maracaibo, Venezuela 4005 \\ †Department of Animal and Poultry Science, and \\ ‡Department of Biomedical Sciences, University of Guelph, Ontario, N1G 2W1 Canada
}

\section{ABSTRACT}

The decline in mammary epithelial cell number as lactation progresses may be due, in part, to oxidative stress. Selenium is an integral component of several antioxidant enzymes. The present study was conducted to examine the effect of oxidative stress and selenomethionine (SeMet) on morphology, viability, apoptosis, and proliferation of bovine mammary epithelial cells (BMEC) in primary culture. Cells were isolated from mammary glands of lactating dairy cows and grown for $3 \mathrm{~d}$ in a low-serum gel system containing lactogenic hormones and 0 or $100 \mu M \mathrm{H}_{2} \mathrm{O}_{2}$ with $0,10,20$, or $50 \mathrm{n} M$ SeMet. Hydrogen peroxide stress increased intracellular $\mathrm{H}_{2} \mathrm{O}_{2}$ to 3 times control concentrations and induced a loss of cuboidal morphology, cell-cell contact, and viability of BMEC by $25 \%$. Apoptotic cell number more than doubled during oxidative stress, but proliferating cell number was not affected. Supplementation with SeMet increased glutathione peroxidase activity 2-fold and restored intracellular $\mathrm{H}_{2} \mathrm{O}_{2}$ to control levels with a concomitant return of morphology and viability to normal. Apoptotic BMEC number was decreased $76 \%$ below control levels by SeMet and proliferating cell number was increased 4.2-fold. These findings suggest that SeMet modulated apoptosis and proliferation independently of a selenoprotein-mediated reduction of $\mathrm{H}_{2} \mathrm{O}_{2}$. In conclusion, SeMet supplementation protects BMEC from $\mathrm{H}_{2} \mathrm{O}_{2}$-induced apoptosis and increased proliferation and cell viability under conditions of oxidative stress.

Key words: mammary epithelial cell, selenomethionine, apoptosis, cell proliferation

\section{INTRODUCTION}

Selenium (Se) has a pivotal role in the synthesis and activity of several antioxidant enzymes, particularly

\footnotetext{
Received April 22, 2010.

Accepted October 6, 2010.

${ }^{1}$ Corresponding author: jcant@uoguelph.ca
}

those of the glutathione peroxidase (GPx) superfamily. The best known biological function of this selenoenzyme family is the reduction of hydrogen peroxide $\left(\mathrm{H}_{2} \mathrm{O}_{2}\right)$ and organic peroxides into water or their respective alcohols using glutathione as a reductant. Numerous degenerative diseases in different species are associated with the disruption of this antioxidant mechanism. In dairy cows, retained fetal membranes (BrezinskaSlebodzinska et al., 1994), white muscle disease, and increased risk of mastitis (Kincaid, 1995) are linked to plasma Se deficiency and low GPx activity. Although evidence associating Se and GPx activity with mammary health in dairy animals was first detailed more than 2 decades ago (Smith et al., 1984), it is only now becoming clear that milk production in dairy cows is positively related to Se supplementation in areas where soil Se concentration is low (Wang et al., 2009). Nevertheless, the mechanism by which these Se supplements enhance milk yield is unclear.

The decline in daily milk yield as lactation progresses is the consequence of a rate of cell death that is faster than cell renewal by proliferation and differentiation (Capuco et al., 2001). Oxidative damage to secretory cells due to their high biosynthetic activity was proposed as contributing to the lactational decline of secretory cell numbers and milk yield (Hadsell et al., 2007). Reactive oxygen species (ROS), including $\mathrm{H}_{2} \mathrm{O}_{2}$, damage biomolecules such as DNA, causing DNA fragmentation and cell death (Burdon, 1995). Indeed, a significant increase in apoptotic cell number was detected after human breast adenocarcinoma cells (MCF-7) were treated with $150 \mu M \mathrm{H}_{2} \mathrm{O}_{2}$ (Dasari et al., 2006). In addition, morphological modifications and decreased proliferation of cells exposed to 10 to $200 \mu \mathrm{M}$ $\mathrm{H}_{2} \mathrm{O}_{2}$ have been documented (Burdon, 1995; Mori et al., 2004), although not in bovine mammary epithelial cells (BMEC).

The role of selenoproteins in removal of ROS provides a hypothetical link between Se status and secretory cell number. We previously showed that GPx expression and activity, and number and viability of BMEC in culture, were improved by the addition of 10 to $50 \mathrm{nM}$ 
selenomethionine (SeMet) to the media (Miranda et al., 2009). Whether changes in cell proliferation or death were responsible for the stimulatory effect of Se on BMEC number remains unknown. In other cell lines, addition of nanomolar concentrations of Se to the culture media decreased basal and $\mathrm{H}_{2} \mathrm{O}_{2}$-stimulated apoptosis (Yoon et al., 2002; Yeo and Kang, 2007). Effects of low concentrations of Se on proliferation have been studied less; however, it has been reported that $250 \mathrm{nM}$ Se stimulated division of leukemia cells in vitro (Zeng, 2002). These results suggest that cellular antioxidant status may modulate apoptosis and proliferation of BMEC under oxidative stress. In this context, an in vitro model of oxidative stress was employed in which $\mathrm{H}_{2} \mathrm{O}_{2}$ was added directly to determine (1) the effect of oxidative stress on BMEC morphology, viability, apoptosis, and proliferation; (2) the effect of SeMet on $\mathrm{H}_{2} \mathrm{O}_{2}$-stressed BMEC; and (3) whether proliferation or apoptosis is modulated by SeMet.

\section{MATERIALS AND METHODS}

\section{Chemicals, Materials, and Antibodies}

Collagenase type III from Clostridium histolyticum $(400 \mathrm{U} / \mathrm{mL})$ and hyaluronidase $(200 \mathrm{U} / \mathrm{mL})$ were obtained from Worthington Biochemicals (Freehold, NJ). Colloidal silica (Percoll) was purchased from Pharmacia Fine Chemical (Piscataway, NY) and fetal bovine serum (FBS) was acquired from PAA Laboratories Inc. (Etobicoke, Ontario, Canada). An ApopTag kit was obtained from Chemicon (Teluca, CA) and the 5-bromo-2'-deoxyuridine (BrdU) cell proliferation assay kit was purchased from Roche Diagnostics (Laval, Quebec, Canada). CellTiter 96 commercial kit was acquired from Promega (Madison, WI) and a GPx commercial kit from Cayman Chemical (Ann Arbor, MI). Bicinchoninic acid assay was obtained from Pierce (Rockford, IL) and 2'-7'-dihydrodichlorofluorescein diacetate (DCFH-DA) from Molecular Probes Inc. (Eugene, OR). All other chemicals were purchased from Sigma Chemical Co. (Oakville, Ontario, Canada).

Collagen-coated culture slides (2-chamber), 24-well culture plates, 35-mm and 100-mm culture dishes coated with collagen type I from rat tail tendon were purchased from BD Biosciences BioCoat (Bedford, MA), and 96well microplates from Costar (Cambridge, MA). The anti-cytokeratin AE1/AE3 antibody was purchased from Dako (Mississauga, Ontario, Canada).

\section{BMEC Isolation and Culture}

Epithelial cells were isolated as described previously (Miranda et al., 2009) from healthy mammary glands of 8 multiparous, lactating Holstein cows at $97 \pm 12$ DIM, producing $30.0 \pm 5.0 \mathrm{~kg}$ milk/d, culled due to locomotor disorders and reproductive failure from the Elora Dairy Research Centre herd (Elora, Ontario, Canada), and slaughtered at the University of Guelph Meat Laboratory (Guelph, Ontario, Canada). Briefly, minced mammary tissue was digested with collagenase, hyaluronidase, and DNase, and cells were separated by serial filtration. Cells recovered on a Percoll density gradient were $98 \%$ immunopositive to anti-cytokeratin AE1/AE3 antibody (1:100), which verified their epithelial nature. Cells were cultured in media containing $45 \%$ RPMI-1640, 45\% Dulbecco's modified Eagle's medium, $5 \%$ FBS, 2\% antibiotic-antimycotic solution, $1 \mathrm{mM}$ sodium pyruvate, $2 \mathrm{~m} M$ L-glutamine, $40 \mathrm{~m} M$ HEPES buffer, bovine insulin $(5 \mu \mathrm{g} / \mathrm{mL})$, hydrocortisone (1 $\mu \mathrm{g} / \mathrm{mL})$, sheep prolactin $(1 \mu \mathrm{g} / \mathrm{mL})$, murine epidermal growth factor $(5 \mathrm{ng} / \mathrm{mL})$, and bovine transferrin (10 $\mu \mathrm{g} / \mathrm{mL}$ ). Cell counting was performed in an improved Neubauer chamber (Fisher Scientific, Whitby, Ontario, Canada) and the proportion of viable cells was $95 \%$ by trypan blue dye $(0.1 \% \mathrm{wt} / \mathrm{vol})$ exclusion.

\section{Oxidative Stress Model}

To determine the concentration of $\mathrm{H}_{2} \mathrm{O}_{2}$ that would produce cell death rates reported in vivo (Wilde et al., 1997), BMEC were plated at $3 \times 10^{4} / \mathrm{cm}^{2}$ in 24 -well culture plates coated with collagen type I from rat tail tendon and grown to semiconfluent monolayers in a humidified environment $\left(5 \% \mathrm{CO}_{2}\right.$ at $\left.37.5^{\circ} \mathrm{C}\right)$. Cells were exposed to $0,50,100,200,500$, or $1,000 \mu M \mathrm{H}_{2} \mathrm{O}_{2}$ for 24 h. Cells were harvested by trypsinization and counted in a hemocytometer chamber under an inverted light microscope (Leica Microsystems, Heidelberg, Germany) after diluting 1:2 with $0.1 \%$ trypan blue in PBS (Liu and Janeway, 1990). Stained cells were considered dead. The $\mathrm{H}_{2} \mathrm{O}_{2}$ dose of $100 \mu \mathrm{M}$ produced $2.7 \%$ dead cells (Figure 1) and was selected for subsequent oxidative stress experiments.

\section{Cell Morphological Analysis}

Epithelial cells were seeded at an approximate density of $1.0 \times 10^{5}$ into $35-\mathrm{mm}$ tissue culture dishes coated with collagen type I from rat tail tendon, and allowed to attach and spread into monolayers over $48 \mathrm{~h}$ of incubation in a humidified $37.5^{\circ} \mathrm{C}, 5 \% \mathrm{CO}_{2}$ atmosphere. Cells were then treated with 0 or $100 \mu M \mathrm{H}_{2} \mathrm{O}_{2}$ with each of 4 levels of SeMet $(0,10,20$, or $50 \mathrm{n} M)$ for 3 d. Every 24 h, 3 dishes on each treatment were carefully rinsed with ice-cold PBS (pH 7.5) and immediately observed under an inverted light microscope with phase contrast (Leica Microsystems) and photographed using a CoolSNAP 


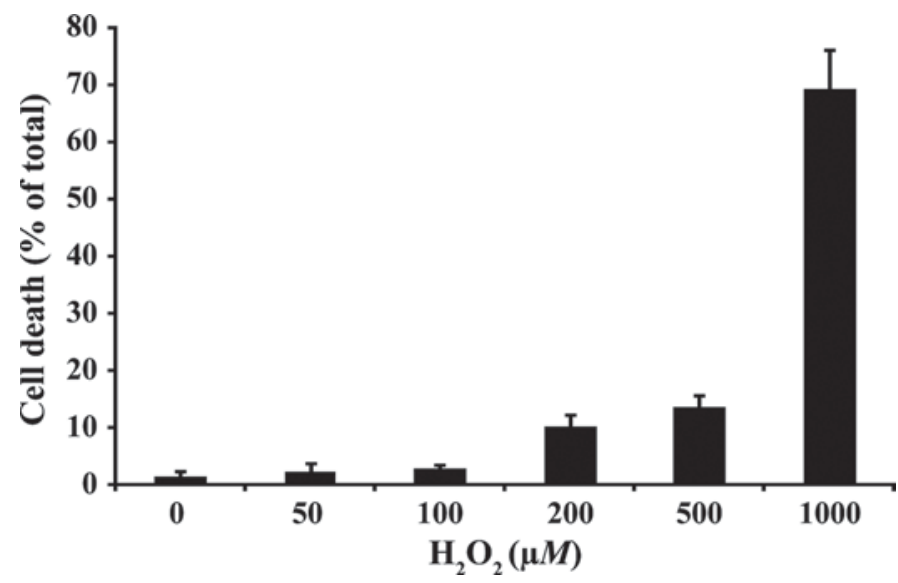

Figure 1. Induction of cell death in primary bovine mammary epithelial cells examined by trypan blue dye exclusion assay. Mammary cells were treated with 50 to $1,000 \mu M \mathrm{H}_{2} \mathrm{O}_{2}$ for $24 \mathrm{~h}$. Data are expressed as mean \pm SEM of 3 independent experiments.

camera (RS Photometrics, Tucson, AZ). Subsequently, monolayers were harvested by trypsinization and collected by centrifugation at $100 \mathrm{~g}$ for $5 \mathrm{~min}$. Cell pellets were washed twice in PBS supplemented with FBS and then fixed in $2 \%$ paraformaldehyde and $2.5 \%$ glutaraldehyde for $24 \mathrm{~h}$ at $4^{\circ} \mathrm{C}$. Samples were dehydrated in a graded series of ethanol $(50 \%, 70 \%, 90 \%$ and $100 \% \mathrm{vol} /$ vol) and infiltrated in LR-White resin (Polysciences, Warrington, PA). Serial sections of polymerized blocks were cut with a Leica/Reichert-Jung Ultracut ultramicrotome (Vienna, Austria), and stained with uranyl acetate and lead citrate. The thin-sections were examined on a Philips CM10 transmission electron microscope (TEM; Philips Electron Optics, Eindhoven, Netherlands) at an accelerating voltage of $80 \mathrm{kV}$ under standard operating conditions. All observations illustrated in the present paper were based on interpretations of at least 5 thin sections from each treatment group.

\section{Cell Death Assay}

Dead adherent cells were determined by terminal dUTP nick end-labeling (TUNEL) assays using the ApopTag kit. The BMEC were grown in 2-chamber, collagen-coated culture slides at an approximate density of $4 \times 10^{5}$ cells/chamber. Incubation times and conditions were as described above. After initiation of SeMet and $\mathrm{H}_{2} \mathrm{O}_{2}$ treatment, cells were fixed in $1 \%$ paraformaldehyde every $24 \mathrm{~h}$ for $3 \mathrm{~d}$. New 3 '-OH ends of double- or single-stranded DNA produced by fragmentation were detected using terminal deoxynucleotidyl transferase enzyme, which chemically labels DNA fragments with a fluorescein nucleotide. Nuclei were counterstained with $1 \mu \mathrm{g} / \mathrm{mL}$ propidium iodide. Cells were visualized in a Leica TCS SP5 multiphoton laser-scanning confocal system (Leica Microsystems) fitted with a Leica DM 6000B microscope and those that showed greenish yellow fluorescence in the nucleus were taken as TUNELpositive. At least 1,000 nuclei were counted for each treatment in 3 independent experiments. Cell death was presented as the percentage of total cells identified as TUNEL-positive.

\section{Cell Proliferation Assay}

Synthesis of DNA was measured with a BrdU cell proliferation assay kit according to the manufacturer's instructions. The BMEC were plated at $4 \times 10^{5}$ cells/ well in 2-chamber collagen-coated culture slides, cultured for $48 \mathrm{~h}$, and treated with the indicated doses of SeMet and $\mathrm{H}_{2} \mathrm{O}_{2}$ for $72 \mathrm{~h}$. Each $24 \mathrm{~h}$ posttreatment, epithelial cells were labeled with $\mathrm{BrdU}$ at $37.5^{\circ} \mathrm{C}$ and $5 \% \mathrm{CO}_{2}$ for $60 \mathrm{~min}$ and then reacted with mouse antibody against BrdU. Unbound antibody was removed by washing, and anti-mouse IgG-alkaline phosphatase was added. Antibody banding complexes were visualized by reacting nitroblue tetrazolium salt and 5-bromo4-chloro-3-indolyl phosphate under an inverted light microscope with phase contrast (Leica Microsystems) using the $20 \times$ objective. At least 1,000 cells in random fields of view were counted for each treatment in 3 independent experiments to quantify the percentage of cells exhibiting nuclear BrdU incorporation.

\section{Cell Viability Assay}

Cell viability under $\mathrm{H}_{2} \mathrm{O}_{2}$ stress was estimated using the CellTiter 96 commercial kit. This kit quantified the cellular conversion of 3-(4,5-dimethylthiazol-2-yl)2,5-diphenyl tetrazolium bromide salt (MTT) into a purple formanza product. Forty-eight hours after seeding cells into 96 -well plates at $2 \times 10^{4}$ cells/well in 100 $\mu \mathrm{L}$, media containing $0 \mu M \mathrm{H}_{2} \mathrm{O}_{2}$, or different levels of SeMet $(0,10,20$ and $50 \mathrm{n} M)$ with $100 \mu M \mathrm{H}_{2} \mathrm{O}_{2}$, was added for continued incubation at $37.5^{\circ} \mathrm{C}$ in $5 \% \mathrm{CO}_{2}$. At 24,48 , and $72 \mathrm{~h}$ posttreatment, MTT solution $(0.5 \mathrm{mg} /$ $\mathrm{mL}$ ) was added to each well and incubated for $4 \mathrm{~h}$ at $37.5^{\circ} \mathrm{C}$ before adding solubilization/stop solution. The solubilized formanza product was measured by spectrophotometry (PowerWave X340, Bio-Tek Instruments Inc., Winooski, VT) at $570 \mathrm{~nm}$. A standard curve of cell number against absorbance was used to identify the linear portion of the curve. All cell viability assays were carried out in triplicate and repeated 3 times.

\section{Measurement of Intracellular GPX Activity in BMEC}

The BMEC were plated $\left(2 \times 10^{6}\right.$ cells $)$ on $100-\mathrm{mm}$ dishes culture coated with collagen type I from rat 
tail tendon and grown to a semiconfluent monolayer in a humidified environment $\left(5 \% \mathrm{CO}_{2}\right.$ at $\left.37.5^{\circ} \mathrm{C}\right)$ for 48 h. Cells were then treated with $\mathrm{H}_{2} \mathrm{O}_{2}$ and SeMet as described earlier. Every $24 \mathrm{~h}$, cells were harvested by mechanical scraping and lysed in $500 \mu \mathrm{L}$ of cold RIPA lysis buffer $(50 \mathrm{~m} M$ Tris- $\mathrm{HCl}, \mathrm{pH} 7.2,150 \mathrm{mM}$ $\mathrm{NaCl}, 0.1 \%$ SDS, $0.5 \%$ sodium deoxycholate, $1.0 \%$ Triton X-100, $10 \mathrm{~m} M$ sodium pyrophosphate, $25 \mathrm{mM}$ $\beta$-glycerophosphate, $2 \mathrm{~m} M$ sodium vanadate, $2.1 \mu \mathrm{g} /$ $\mathrm{mL}$ aprotinin) supplemented with $15 \mu \mathrm{L}$ of protease inhibitor cocktail (104 $\mu M$ 4-(2-aminoethyl) benzenesulfonyl fluoride, $0.08 \mu M$ aprotinin, $2 \mu M$ leupeptin, $4 \mu M$ bestatin, $1.5 \mu M$ pepstatin A, and $1.4 \mu M$ E-64) on ice for $15 \mathrm{~min}$. The remaining homogenates were centrifuged $\left(12,000 \times g, 4^{\circ} \mathrm{C}, 40 \mathrm{~min}\right)$ to remove cellular debris, after which absolute GPx activity recovered in the supernatant was estimated by GPx commercial kit, according to Paglia and Valentine (1967). Activity of GPx was normalized to total cell protein quantified by bicinchoninic acid assay.

\section{Detection of Intracellular Hydrogen Peroxide}

Intracellular $\mathrm{H}_{2} \mathrm{O}_{2}$ concentration was measured from the oxidation of 2'-7'-dihydrodichlorofluorescein diacetate to the fluorescent compound 2'-7'-dichlorofluorescein $(\mathbf{D C F})$ in a spectrofluorometer as described previously (Grisham, 2008). The BMEC $\left(2 \times 10^{6}\right)$ were cultured and treated with SeMet and $\mathrm{H}_{2} \mathrm{O}_{2}$ as indicated above for $72 \mathrm{~h}$ in 100-mm dishes coated with collagen type I from rat tail tendon. Every $24 \mathrm{~h}$, monolayers were washed 3 times with PBS (pH 7.5). Epithelial cells were incubated with serum-free media containing 30 $\mu M$ DCFH-DA for $90 \mathrm{~min}$ at $37^{\circ} \mathrm{C}$ in dark conditions. Postincubation, BMEC were washed 3 times with PBS and lysed in $0.5 \%$ (wt/vol) SDS solution. The $100 \mu \mathrm{L}$ of cell lysate was transferred to flat-bottom, 96-well microplates and analyzed in a microplate reader (Wallac Victor 1420 Multilaber Counter, Perkin-Elmer, Wellesley, MA) with excitation and emission wavelengths set at 485 and $530 \mathrm{~nm}$, respectively. After subtracting fluorescence of a blank cell suspension without DCFH-DA, fluorescence was expressed per milligram of protein.

\section{Statistical Analysis}

All experiments were carried out in triplicate and repeated independently 3 times, and numerical data are expressed as least squares means \pm SEM. A mixed model in SAS (Windows version 9.1.3, SAS Institute Inc., Cary, NC) with repeated measures over time was used to analyze the effects of $\mathrm{H}_{2} \mathrm{O}_{2}(100 \mu M)$ and 4 levels of SeMet $(0,10,20$, or $50 \mathrm{nM})$ on BMEC apoptosis, viability, proliferation, GPx activity and intracellular level of $\mathrm{H}_{2} \mathrm{O}_{2}$ during $3 \mathrm{~d}$ with the following model:

$$
\mathrm{Y}_{\mathrm{ijk}}=\mu+\mathrm{M}_{\mathrm{i}}+\mathrm{T}_{\mathrm{j}}+\mathrm{MT}_{\mathrm{ij}}+\text { error }_{\mathrm{k}(\mathrm{ij})} \text {, }
$$

where $\mu=$ overall mean, $M_{i}=$ fixed effect of treatment ( $\mathrm{i}=1$ to 5$), \mathrm{T}_{\mathrm{j}}=$ repeated time effect ( $\mathrm{j}=1$ to 3$), \mathrm{MT}_{\mathrm{ik}}$ $=$ treatment by time interaction effect, and error $_{\mathrm{k}(\mathrm{ij})}=$ experimental error ( $\mathrm{k}=1$ to 3 ). Covariance was fitted with a compound symmetry structure (Kaps and Lamberson, 2004). Differences among treatment means at each time point were evaluated using the pdiff option of SAS (SAS Institute Inc.). Significance was declared at $P<0.05$.

\section{RESULTS}

\section{Effect of SeMet and $\mathrm{H}_{2} \mathrm{O}_{2}$ on Intracellular $\mathrm{H}_{2} \mathrm{O}_{2}$ Levels in BMEC}

The $100 \mu M \quad \mathrm{H}_{2} \mathrm{O}_{2}$ treatment without SeMet increased $\mathrm{H}_{2} \mathrm{O}_{2}$ concentrations inside BMEC to 2 and 3 times control concentrations $(P<0.001)$, according to DCFH-DA oxidation results (Figure 2). All concentrations of SeMet reduced intracellular $\mathrm{H}_{2} \mathrm{O}_{2}$ to control concentrations except at $72 \mathrm{~h}$, when $10 \mathrm{n} M$ SeMet only caused half of the $\mathrm{H}_{2} \mathrm{O}_{2}$ decrease $(P<0.001)$.

\section{Effect of SeMet on GPx Activity in BMEC Under $\mathrm{H}_{2} \mathrm{O}_{2}$ Treatment}

At 24,48 , and $72 \mathrm{~h}$, absolute GPx activity was 3 times higher $(P<0.001)$ in secretory cells treated simultaneously with $\mathrm{H}_{2} \mathrm{O}_{2}$ and SeMet than in cells treated only with 0 or $100 \mu M \mathrm{H}_{2} \mathrm{O}_{2}$ (Figure 3). Although no effect of incubation time on GPx activity was observed during the first $48 \mathrm{~h}$, secretory cells exposed to $\mathrm{H}_{2} \mathrm{O}_{2}$ with $10 \mathrm{n} M$ SeMet exhibited a decrease in the activity of this selenoprotein by $72 \mathrm{~h}$ of incubation. Absolute GPx activity was 1.5 -fold and 1.6 -fold higher $(P<0.05)$ in cells cultured with 20 and $50 \mathrm{n} M$ SeMet, respectively, than in cells cultured with $10 \mathrm{n} M$ SeMet at $72 \mathrm{~h}$. No effect of $\mathrm{H}_{2} \mathrm{O}_{2}$ treatment on GPx activity was observed at 24 and $72 \mathrm{~h}$ of incubation $(P>0.41)$; however, GPx activity was reduced $33 \%$ by $\mathrm{H}_{2} \mathrm{O}_{2}$ at $48 \mathrm{~h}(P<0.05)$.

\section{Influence of SeMet on Cell Morphology in BMEC Exposed to Subcytotoxic Level of $\mathrm{H}_{2} \mathrm{O}_{2}$}

Before treatment, BMEC were flat and homogeneous in size and appearance, with morphology in culture typical of epithelial cells (cobblestone conformation). These characteristics changed after $48 \mathrm{~h}$ of treatment. 


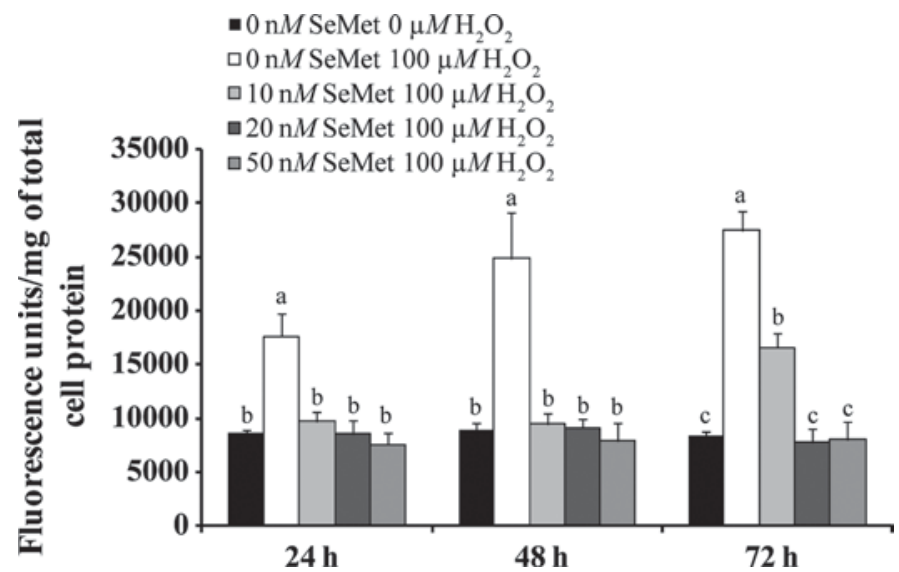

Figure 2. Selenomethionine (SeMet) decreased intracellular levels of $\mathrm{H}_{2} \mathrm{O}_{2}$ in primary bovine mammary epithelial cells during oxidative stress. Results are means \pm SEM of 3 independent experiments. Means within each period with different letters are different $(P<0.05)$.

Secretory cells treated with a sublethal level of $\mathrm{H}_{2} \mathrm{O}_{2}$ without SeMet gradually became enlarged and elongated compared with untreated cells (data not shown). These changes were more marked after $72 \mathrm{~h}$, where cells lost their cuboidal morphology and exhibited large vacuoles in the cytoplasm (Figure 4A). Additionally, zones devoid of cells were observed, which suggests disruption of the integrity of cell-to-cell contacts (Figure $4 \mathrm{~A})$. In contrast, when BMEC were exposed to SeMet in addition to $\mathrm{H}_{2} \mathrm{O}_{2}$, no morphologic changes were detected at $72 \mathrm{~h}$ (Figure 4B). The control group showed few unhealthy cells with cell elongation (Figure 4C).

Ultrastructural features were examined by transmission electron microscopy at $72 \mathrm{~h}$ of treatment. Normal cells were observed in all treatments, displaying lipid droplets in their cytoplasm, a clear nucleus and intact specialized surface structures such as microvilli (Figure 5A). Apoptotic cells were detected across treatments,

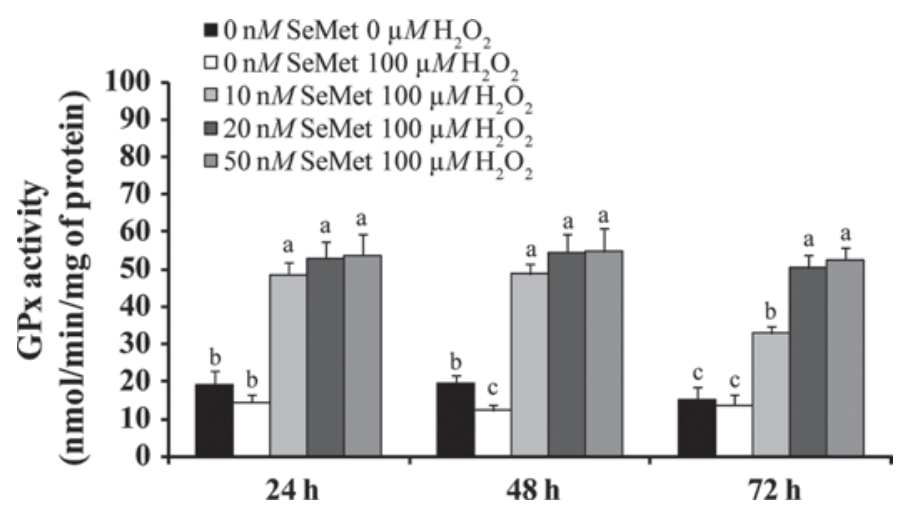

Figure 3. Effect of selenomethionine (SeMet) on glutathione peroxidase activity $(\mathrm{GPx})$ of primary bovine mammary epithelial cells under $\mathrm{H}_{2} \mathrm{O}_{2}$ stress. Data are expressed as means \pm SEM of 3 independent experiments. Means within each period with different letters are different $(P<0.05)$. showing margination and condensation of nuclear chromatin into more densely packed material along the nuclear membrane, intact plasma membrane, with prominent cytoplasmic vacuoles and loss of microvilli (Figure 5B).

\section{Effect of SeMet on DNA Fragmentation in $\mathrm{BMEC}$ Under $\mathrm{H}_{2} \mathrm{O}_{2}$ Treatment}

Fragmentation of DNA is a well-characterized biochemical marker of cell death. Exposure of BMEC to $100 \mu M \mathrm{H}_{2} \mathrm{O}_{2}$ without SeMet resulted in an increase $(P<0.001)$ in the proportion of TUNEL-positive cells at all time points (Figure 6). Over $72 \mathrm{~h}$ of incubation, TUNEL-positive cell percentage increased in a timedependent manner $(P<0.001)$ in all treatments, but the increase was greatest at $129 \%$ with $0 \mathrm{n} M$ SeMet + $100 \mu M \mathrm{H}_{2} \mathrm{O}_{2}$ compared with $39 \%$ on the control. When SeMet-containing medium was added, a reduction in TUNEL-positive cells was detected at each time point $(P<0.001)$. Maximal protection was achieved at $24 \mathrm{~h}$. The decrease in TUNEL-positive cells was $76 \%$ for 20 and $50 \mathrm{n} M$ SeMet, and $41 \%$ for $10 \mathrm{n} M$ SeMet compared with $0 \mathrm{n} M$ SeMet $+100 \mu M \mathrm{H}_{2} \mathrm{O}_{2}$.

\section{Effect of SeMet on Cell Proliferation in $\mathrm{BMEC}$ Under $\mathrm{H}_{2} \mathrm{O}_{2}$ Treatment}

According to the BrdU incorporation assay (Figure 7), no effect of $\mathrm{H}_{2} \mathrm{O}_{2}$ stress on numbers of cells with new nuclear DNA synthesis was found compared with control $(P>0.38)$. In contrast, SeMet at all doses increased proliferating cell number compared with 0 and $100 \mu M \mathrm{H}_{2} \mathrm{O}_{2}$ treatments $(P<0.001)$, and to a greater extent as incubation time increased $(P<0.001)$. At 72 $\mathrm{h}$, proliferating cell number was 4.2 -fold higher on all SeMet treatments.

\section{Effect of SeMet on Viable Cell Number in $\mathrm{BMEC}$ Under $\mathrm{H}_{2} \mathrm{O}_{2}$ Treatment}

After $72 \mathrm{~h}$ of incubation, $100 \mu M \mathrm{H}_{2} \mathrm{O}_{2}$ reduced the number of viable BMEC by $25 \%(P<0.001)$ compared with the control (Figure 8). In contrast, addition of SeMet to media increased $(P<0.001)$ viable cells throughout the experimental period in a time- and dose-dependent manner. Secretory cells cultured with both 20 and $50 \mathrm{n} M$ SeMet exhibited higher viable numbers $(P<0.001)$ than those grown with $10 \mathrm{n} M$ SeMet.

\section{DISCUSSION}

\section{$\mathrm{H}_{2} \mathrm{O}_{2}$ Stress Changes Morphology, Increases Apoptosis, and Has No Effect on Proliferation of BMEC}

To study the antioxidant role of SeMet in BMEC dynamics, an oxidative stress model was used where 

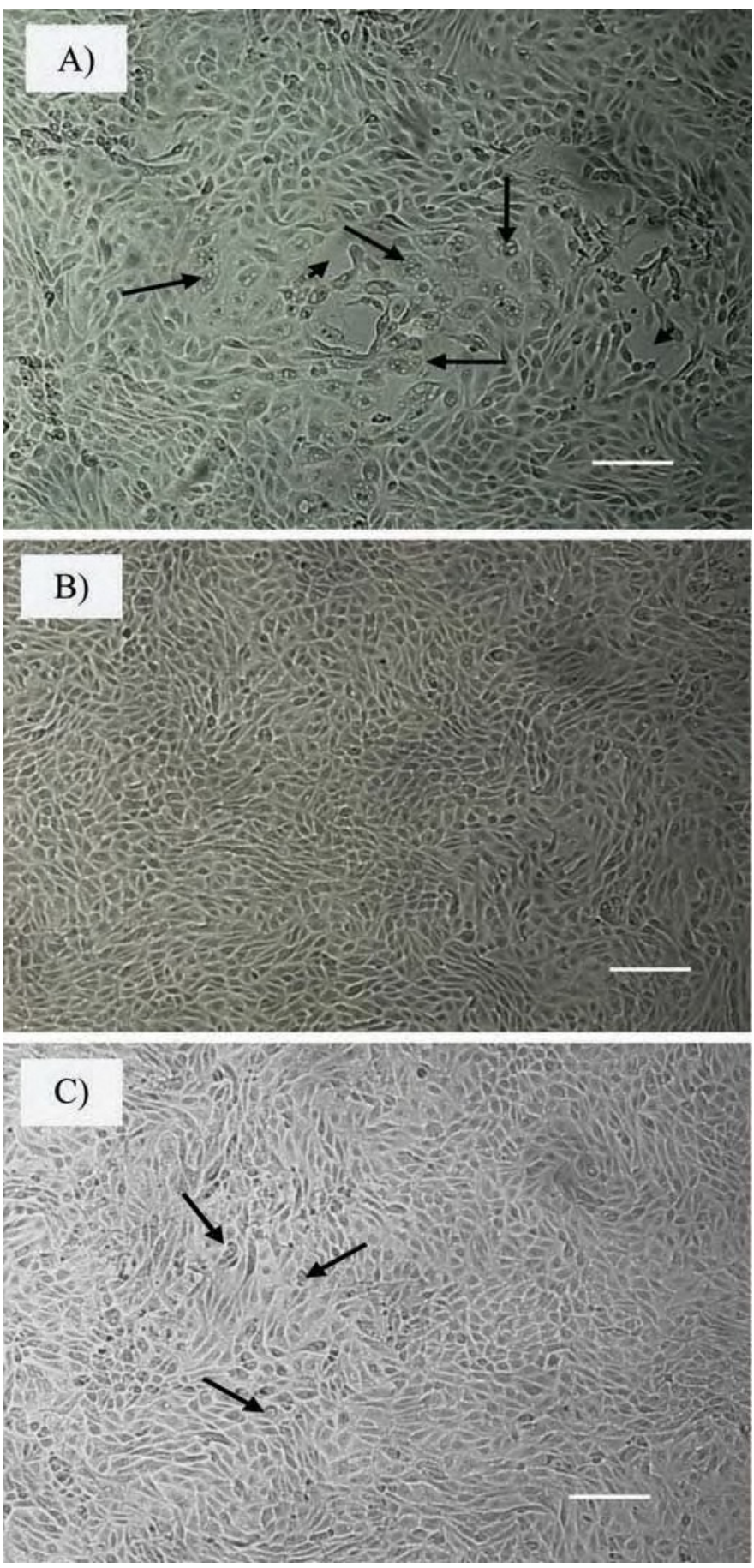

Figure 4. Representative phase-contrast photomicrographs of living bovine mammary epithelial cells illustrating the effect of selenomethionine (SeMet) on morphological changes under $\mathrm{H}_{2} \mathrm{O}_{2}$ stress. A) Mammary cells exposed to $100 \mu M \mathrm{H}_{2} \mathrm{O}_{2}$ after $72 \mathrm{~h}$ became enlarged, elongated, lost their cuboidal shape, with enlarged cytoplasmic vacuoles (arrows) and disrupted cell-cell contacts (arrowheads); B) cells under $\mathrm{H}_{2} \mathrm{O}_{2}$ stress treated with $50 \mathrm{n} M$ SeMet for $72 \mathrm{~h}$ without morphological changes; C) cells grown without $\mathrm{H}_{2} \mathrm{O}_{2}$ or SeMet after $72 \mathrm{~h}$, revealing few unhealthy cells with elongated shape (arrows). Bar $=50$ $\mu \mathrm{m}$. Color version available in the online PDF.
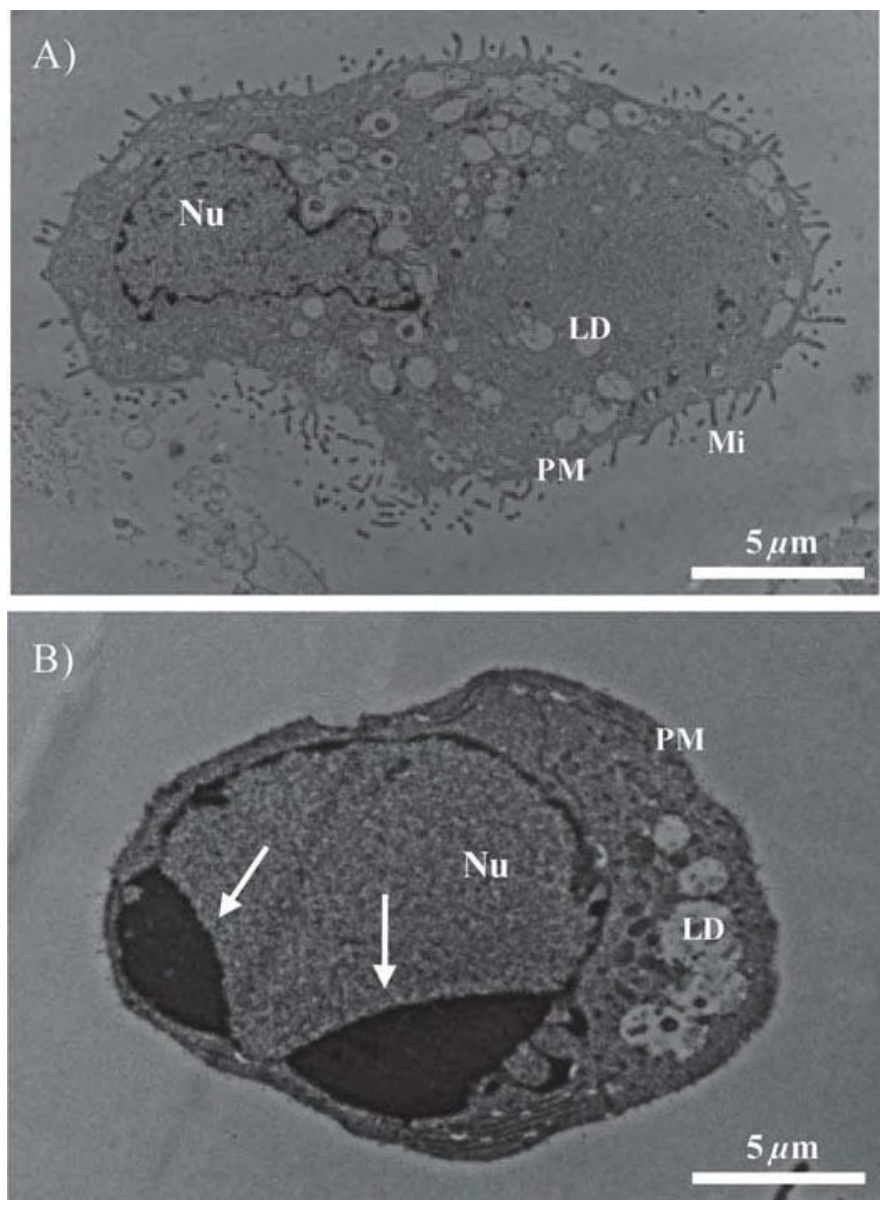

Figure 5. Transmission electron micrographs of cultured bovine mammary epithelial cells. A) A healthy cell displaying lipid droplets $(\mathrm{LD})$, a clear nucleus $(\mathrm{Nu})$ and intact plasma membrane $(\mathrm{PM})$ with microvilli (Mi) were seen in the 5 treatments, and $\mathrm{B}$ ) an apoptotic cell exhibiting marginal condensation of nuclear chromatin (arrows), intact $\mathrm{PM}$, and a loss of Mi and LD were detected in all treatments.

$100 \mu M \mathrm{H}_{2} \mathrm{O}_{2}$ was added to BMEC culture media. The $\mathrm{H}_{2} \mathrm{O}_{2}$-induced enlargement and elongation of cells that were observed over $3 \mathrm{~d}$ was reported previously in mouse mammary epithelial cells (Mori et al., 2004), as was the loosening of gap junctions and reorientation of the cytoskeleton (Alexandrova et al., 2006). Prolonged exposure to $\mathrm{H}_{2} \mathrm{O}_{2}$ may result in malignant transformation of epithelial cells (Mori et al., 2004), but the BMEC under oxidative stress for $72 \mathrm{~h}$ retained their epithelial phenotype as evidenced by detection of cytokeratins.

The MTT assay indicated the number of viable cells in a sample (Denizot and Lang, 1986). The decrease in MTT index with $\mathrm{H}_{2} \mathrm{O}_{2}$ stress appears to be caused by increased apoptosis alone, because the proportion of TUNEL-positive cells increased and proliferating cell number did not change. Electron microscopy revealed morphological features in unhealthy cells typi- 


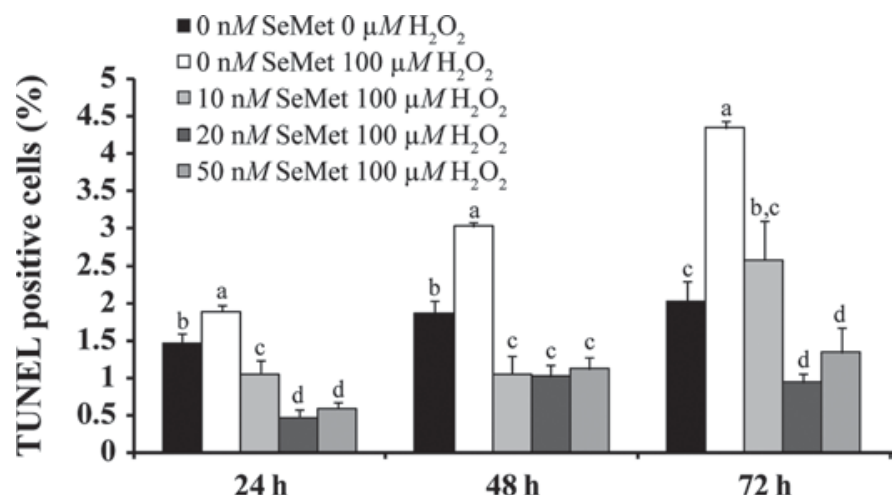

Figure 6. Inhibitory effect of selenomethionine (SeMet) on apoptosis in primary bovine mammary epithelial cells under $\mathrm{H}_{2} \mathrm{O}_{2}$ stress. Results are means \pm SEM from 1,000 nuclei for each treatment in 3 independent experiments. Means within each period with different letters are different $(P<0.05)$. TUNEL $=$ terminal dUTP nick endlabeling.

cal of apoptosis, suggesting that DNA fragmentation detected in the TUNEL assay was due to apoptosis, as opposed to other types of cell death (such as necrosis) in which DNA fragmentation also occurs. Apoptotic features observed included margination and condensation of chromatin, as well as loss of microvilli and plasma membranes remained intact (Krysko et al., 2008). There was no evidence of necrosis such as swollen mitochondria and loss of plasma membrane integrity in unhealthy cells. In several cell types extracellular $\mathrm{H}_{2} \mathrm{O}_{2}$ concentrations up to $200 \mu M$ induce apoptosis, but concentrations greater than $1 \mathrm{mM}$ induce death by necrosis (Creagh et al., 2000).

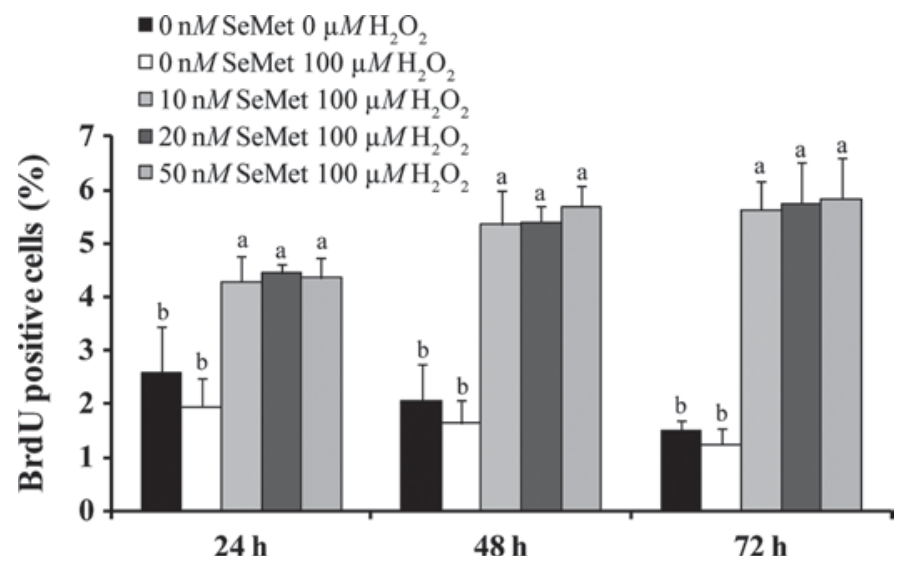

Figure 7. Stimulatory effect of selenomethionine (SeMet) on proliferation of primary bovine mammary epithelial cells (BMEC) under $\mathrm{H}_{2} \mathrm{O}_{2}$ stress. The number of BMEC with BrdU incorporation were counted and related to the total BMEC number by percentage. Data are expressed as means \pm SEM of 3 independent experiments. Means within each period with different letters are different $(P<0.05)$. BrdU $=5$-bromo-2'-deoxyuridine.
Some cell types respond to $\mathrm{H}_{2} \mathrm{O}_{2}<200 \mu M$ with an increase in proliferation (Rao and Berk, 1992; Sigaud et al., 2005). Other cell types respond by decreasing proliferation rate (Rao and Berk, 1992). Hydrogen peroxide appears to act as a second messenger for some of the proliferative effects of growth factors (Burdon, 1995), whereas the mechanism of antiproliferative effects is not well characterized. No effect of $100 \mu M \mathrm{H}_{2} \mathrm{O}_{2}$ was observed on BMEC proliferation, supporting the lack of effect seen on myofibroblast proliferation (Waghray et al., 2005).

\section{SeMet Increases GPx Activity and Reverses ROS Effects}

We have previously shown that 10 to $50 \mathrm{n} M$ SeMet in the incubation medium increased GPx expression and activity in primary cultures of BMEC (Miranda et al., 2009). In this experiment, these increases in GPx activity (when extracellular $\mathrm{H}_{2} \mathrm{O}_{2}$ is $100 \mu M$ ) were associated with a return of intracellular $\mathrm{H}_{2} \mathrm{O}_{2}$ concentrations to the baseline level at $0 \mu M$ extracellular $\mathrm{H}_{2} \mathrm{O}_{2}$. Apparently, GPx levels at $0 \mathrm{n} M$ SeMet were not sufficient to handle the peroxide load imposed by $100 \mu M \mathrm{H}_{2} \mathrm{O}_{2}$. Further support for this conclusion comes from the 10 $\mathrm{n} M$ SeMet concentration at $72 \mathrm{~h}$, where a decrease in GPx activity coincided with an increase in $\mathrm{H}_{2} \mathrm{O}_{2}$ fluorescence.

Reduction of intracellular $\mathrm{H}_{2} \mathrm{O}_{2}$ to baseline by GPx appeared to reverse the effect of extracellular $\mathrm{H}_{2} \mathrm{O}_{2}$ on BMEC morphology, viable cell number, and apoptosis, as all 3 of these variables returned at least to control levels. Similarly, Se reversed the increase in apoptosis and decrease in cell number induced by up to $250 \mu M$ $\mathrm{H}_{2} \mathrm{O}_{2}$ in normal and cancerous cells (Yoon et al., 2002;

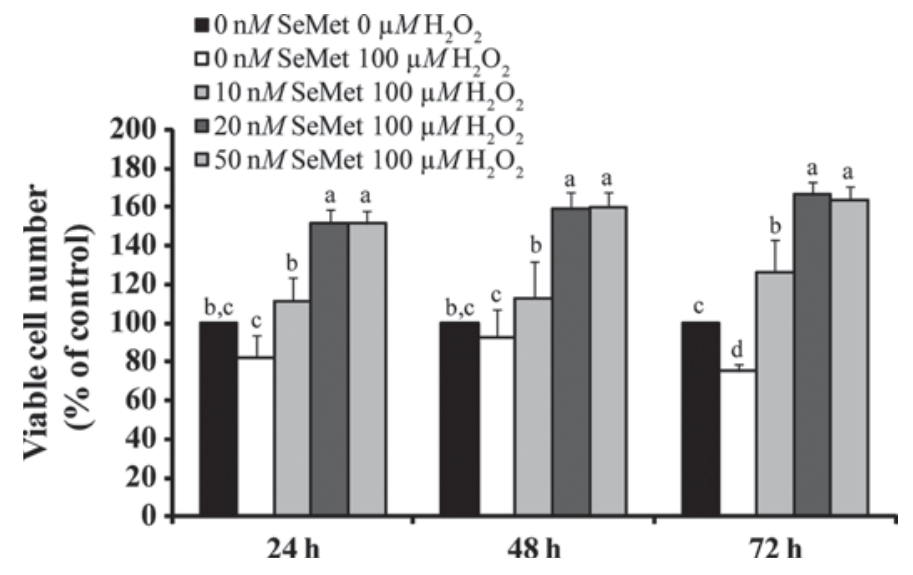

Figure 8. Effect of selenomethionine (SeMet) on viable bovine mammary epithelial cell number under $\mathrm{H}_{2} \mathrm{O}_{2}$ stress. Data are expressed as means \pm SEM of 3 independent experiments. Means within each period with different letters are different $(P<0.05)$. 
Yeo and Kang, 2007). Therefore, the effects of Se on BMEC survival can be explained, in part, by its antioxidative functions.

\section{SeMet Affects Apoptosis and Proliferation Independent of Oxidative Status}

Selenomethionine caused intracellular $\mathrm{H}_{2} \mathrm{O}_{2}$ concentrations to return to the control level, but apoptotic cell number decreased to below control level. Likewise, proliferating cell number was not affected by $\mathrm{H}_{2} \mathrm{O}_{2}$, but was increased by SeMet. Together these results indicated that SeMet affected apoptosis and proliferation independently of a GPx-mediated decrease in intracellular $\mathrm{H}_{2} \mathrm{O}_{2}$. Yoon et al. (2002) found a stimulation of HT1080 cell population growth to higher than control levels when $2 \mu M$ Se was added to media containing $100 \mu M \mathrm{H}_{2} \mathrm{O}_{2}$. Even without exogenous $\mathrm{H}_{2} \mathrm{O}_{2}$ exposure, SeMet up to $50 \mathrm{n} M$ accelerated BMEC population growth over $5 \mathrm{~d}$ of culture (Miranda et al., 2009). The anti-apoptotic effects of Se, independent of oxidative stress, have been attributed to activation of the insulin signaling kinase Akt (Yoon et al., 2002).

\section{CONCLUSIONS}

Oxidative stress in BMEC increased the number of apoptotic cells, decreased cell viability, and perturbed cell morphology, without affecting cell proliferation. Selenomethionine was able to reverse these negative effects of $\mathrm{H}_{2} \mathrm{O}_{2}$ by increasing absolute GPx activity and reducing intracellular levels of $\mathrm{H}_{2} \mathrm{O}_{2}$. Furthermore, SeMet decreased the number of apoptotic BMEC and increased proliferating cell number independent of selenoprotein-mediated reductions in $\mathrm{H}_{2} \mathrm{O}_{2}$. The turnover of mammary epithelial cells is a major determinant of the slope of the lactation curve after peak lactation. If the reduction in apoptosis and increase in proliferation brought about by SeMet in BMEC under oxidative stress in vitro can be recapitulated in vivo, it could enhance lactation persistency in dairy cows.

\section{ACKNOWLEDGMENTS}

This study was supported by grants from Dairy Farmers of Ontario (Mississauga), NSERC Canada (Ottawa, Ontario), the Ontario Ministry of Agriculture, Food and Rural Affairs (Guelph), and the University of Zulia (Maracaibo, Venezuela). We thank Michaela StrüderKypke, Bob Harris, Brian McDougall, Sam Leo, and Dianne Moyles (University of Guelph) for their skillful technical assistance.

\section{REFERENCES}

Alexandrova, A. Y., P. B. Kopnin, J. M. Vasiliev, and B. P. Kopnin. 2006. ROS up-regulation mediates Ras-induced changes of cell morphology and motility. Exp. Cell Res. 312:2066-2073.

Brezinska-Slebodzinska, E., J. K. Miller, J. D. Quigley, J. R. Moore, and F. C. Madsen.. 1994. Antioxidant status of dairy cows supplemented prepartum with vitamin E and selenium. J. Dairy Sci. 77:3087-3095.

Burdon, R. H. 1995. Superoxide and hydrogen peroxide in relation to mammalian cell proliferation. Free Radic. Biol. Med. 18:775794.

Capuco, A. V., D. L. Wood, R. Baldwin, K. Mcleod, and M. J. Paape. 2001. Mammary cell number, proliferation, and apoptosis during a bovine lactation: Relation to milk production and effect of bST. J. Dairy Sci. 84:2177-2187.

Creagh, E. M., D. Sheehan, and T. G. Cotter. 2000. Heat shock proteins-Modulators of apoptosis in tumour cells. Leukemia 14:1161-1173.

Dasari, A., J. N. Bartholomew, D. Volonte, and F. Galbiati. 2006. Oxidative stress induces premature senescence by stimulating caveolin-1 gene transcription through p38 mitogen-activated protein kinase/Sp1-mediated activation of two GC-rich promoter elements. Cancer Res. 22:10805-10814.

Denizot, F., and R. Lang. 1986. Rapid colorimetric assay for cell growth and survival. Modifications to the tetrazolium dye procedure giving improved sensitivity and reliability. J. Immunol. Methods 89:271-277.

Grisham, M. B. 2008. Methods to detect reactive metabolites of oxygen and nitrogen. Pages 272-276 in Redox Biochemistry. R. Banerjee, ed. John Wiley and Sons Publishers, Hoboken, NJ.

Hadsell, D., J. George, and D. Torres. 2007. The declining phase of lactation: Peripheral or central, programmed or pathological? J. Mammary Gland Biol. Neoplasia 12:59-70.

Kaps, M., and W. Lamberson. 2004. Biostatistics for Animal Science. CABI Publishing, Cambridge, MA.

Kincaid, R. L. 1995. The biological basis for selenium requirements of animals. Prof. Anim. Sci. 11:26-29.

Krysko, D. V., T. V. Berghe, K. D'Herde, and P. Vandenabeele. 2008. Apoptosis and necrosis: Detection, discrimination and phagocytosis. Methods 44:205-221.

Liu, Y., and C. A. Janeway. 1990. Interferon $\gamma$ plays a critical role in induced cell death of effector T cell: A possible third mechanism of self-tolerance. J. Exp. Med. 172:1735-1739.

Miranda, S. G., Y. J. Wang, N. G. Purdie, V. R. Osborne, B. L. Coomber, and J. P. Cant. 2009. Selenomethionine stimulates the expression of glutathione peroxidase 1 and 3 of bovine mammary epithelial cells in primary cells culture. J. Dairy Sci. 92:26702683.

Mori, K., M. Shibanuma, and K. Nose. 2004. Invasive potential induced under long-term oxidative stress in mammary epithelial cells. Cancer Res. 64:7464-7472.

Paglia, D. E., and W. N. Valentine. 1967. Studies on the quantitative and qualitative characterization of erythrocyte glutathione peroxidase. J. Lab. Clin. Med. 70:158-169.

Rao, G. N., and B. C. Berk. 1992. Active oxygen species stimulate vascular smooth muscle cell growth and proto-oncogene expression. Circ. Res. 70:593-599.

Sigaud, S., P. Evelson, and B. Gonzalez-Flecha. 2005. $\mathrm{H}_{2} \mathrm{O}_{2}$-induced proliferation of primary alveolar epithelial cells is mediated by MAP kinases. Antioxid. Redox Signal. 7:6-13.

Smith, K. L., J. H. Harrison, D. D. Hancock, D. A. Todhunter, and H. R. Conrad. 1984. Effect of vitamin E and selenium supplementation on incidence of clinical mastitis and duration of clinical symptoms. J. Dairy Sci. 67:1293-1300.

Waghray, M., Z. Cui, J. C. Horowitz, I. M. Subramanian, F. J. Martinez, G. B. Toews, and V. J. Thannickal. 2005. Hydrogen peroxide is a diffusible paracrine signal for the induction of epithelial cell death by activated myofibroblasts. FASEB J. 19:854-856. 
Wang, C., Q. Liu, W. Z. Yang, Q. Dong, X. M. Yang, D. C. He, P. Zhang, K. H. Dong, and Y. X. Huang. 2009. Effects of selenium yeast on rumen fermentation, lactation performance and feed digestibilities in lactating dairy cows. Livest. Sci. 126:239-244.

Wilde, C. J., C. V. Addey, P. Li, and D. G. Fernig. 1997. Programmed cell death in bovine mammary tissue during lactation and involution. Exp. Physiol. 82:943-953.

Yeo, J. E., and S. K. Kang. 2007. Selenium effectively inhibits ROSmediated apoptotic neural precursor cell death in vitro and in vivo in traumatic brain injury. Biochim. Biophys. Acta 1772:1199 1210 .

Yoon, S. O., M. Kim, S. Park, D. Kim, J. Chung, and A. Chung. 2002. Selenite suppresses hydrogen peroxide-induced cell apoptosis through inhibition of ASK1/JNK and activation of PI3-K/Akt pathways. FASEB J. 16:111-113.

Zeng, H. 2002. Selenite and selenomethionine promote HL-60 cell cycle progression. J. Nutr. 132:674-679. 